\title{
Akuntabilitas Pengelolaan Anggaran Tahun 2014-2015 Pada Badan Pengelolaan Keuangan dan Aset Daerah (BPKAD) Kabupaten Bone
}

\author{
Agustiani \\ Institut Agama Islam Negeri (IAIN) Bone \\ agustianiiainbone@yahoo.co.id
}

\author{
Nahariah \\ Sekolah Tinggi Agama Islam (STAI) Al -Furqan Makassar \\ nahariah@gmail.com
}

\begin{abstract}
This study aims to find out (1) What is the description of the implementation of performancebased Budget management accountability at the Regional Financial and Asset Management Agency of the Regency. Bone. (2) Constraints in implementing performance-based Budget Management accountability at the Regional Financial and Asset Management Agency, Kab. Bone. (3) What is the solution to the obstacles to the implementation of performance-based Budget Management accountability at the Regional Financial and Asset Management Agency of the Regency. Bone. The results of this study indicate that in the budget management accountability activities at the Regional Financial and Asset Management Agency in Kabupaten Bone, it has implemented 4 (four) accountability principles, namely budget planning, budgeting, budget execution, and budget accountability. However, there are still obstacles from the application of budget management accountability principles, namely weaknesses in Human Resources and Coordination in budgeting. As for the solutions to these constraints, as long as they are adapted to existing activities, follow the schedule and need more maximal socialization to the parties. party responsible for caramusyawaramufakat Regional Government Budget Team.
\end{abstract}

Keywords: Accountability, Budget Management.

\begin{abstract}
Abstrak
Penelitian ini bertujuan untuk mengetahui (1) Bagaimana gambaran implementasi akuntabilitas pengelolaan Anggaran yang berbasis kinerja pada Badan Pengelolaan Keuangan Dan Aset Daerah Kab. Bone., (2)Kendala implementasi akuntabilitas Pengelolaan Anggaran yang berbasis kinerja pada Badan Pengelolaan Keuangan Dan Aset Daerah Kab. Bone., (3) Bagaimana solusi terhadap kendala implementasi akuntabilitas Pengelolaan Anggaran yang berbasis kinerja pada Badan Pengelolaan Keuangan Dan Aset Daerah Kab. Bone. Hasil penelitian ini menunjukkan bahwa dalam kegiatan akuntabilitas pengelolaan anggaran pada Badan Pengelolaan Keuangan dan Aset Daerah Kabupaten Bone sudahmenerapkan 4 (empat) prinsip akuntabilitas yang dilaksanakan yaitu perencanaan anggaran, penganggaran, pelaksanaan anggaran, dan pertanggung jawaban anggaran. Akan tetapi Dari penerapan prinsip
\end{abstract}

Jurnal Ilmiah Al Tsarwah

Program Magister Program Studi Ekonomi Syariah

Institut Agama Islam Negeri (IAIN) Bone

71 
akuntabilitas pengelolaan anggaran masih terdapat kendala, yaitu kelemahan pada Sumber Daya Manusia dan Koordinasi dalam penyusunan anggaran.Adapun solusi terhadap kendala tersebut,yaitu sepanjang disesuaikan dengan kegiatan yang ada,mengikuti scedul dan perlu adanya sosialisasi yang lebih maksimal kepada pihak-pihak yang bertanggungjawab dengancaramusyawaramufakat Tim AnggaranPemerintah Daerah.

\section{Kata Kunci : Akuntabilitas, PengelolaanAnggaran.}

\section{PENDAHULUAN}

Akuntabilitas merupakan prinsip dari good governance. Pelaksanaan good governance sangat diperlukan untuk membangun dan meningkatkan kepercayaan masyarakat kepada suatu organisasi. Perwujudan tata kelola yang baik (good governance) dan bersih secara umum harus berdasarkan prinsip-prinsip keterbukaan dan transparansi, akuntabilitas, efektif dan efisien, menjunjung tinggi supremasi hukum, demokrasi, responsif, dan membuka partisipasi masyarakat, merupakan tuntutan sekaligus. kebutuhan yang mutlak untuk mencapai tujuan pembangunan. ${ }^{1}$

Terselenggaranya Good Governance Merupakan persyaratan bagi setiap pemerintah untuk mewujudkan aspirasi dan mencapai tujuan serta cita- cita bangsa dan bernegara. oleh karena itu diperlukan pengembangan dan penetapan sistem pertanggungjawaban yang tepat, jelas, terukur, sehingga penyelenggaraan pemerintahan dan pengelolaan keuangan selalu berdaya guna, berhasil guna, bersih dan bertanggungjawab serta bebas dari korupsi, kolusi, dan nepotisme. ${ }^{2}$

Upaya pengembangan tersebut sejalan dan berdasarkan pada TAP MPR RI Nomor XI/MPR/1989 tentang penyelenggaraan negara yang bersih dan bebasKorupsi, Kolusi dan Nepotisme dan undang-undang Nomor 28 Tahun 1999 tentang penyelenggaraan Negara yang bersih dan bebas Korupsi, Kolusi dan Nepotisme.

${ }^{1}$ Novie Kiftiah Maries, dkk, Menelaah Transparansi Dan Akuntabilitas Pengelolaan Keuangan Pada Yayasan Pendidikan Full Day Mardlatillah Singaraja, JurusanAkuntansi Program S1,Volume: 7 No: 1 Tahun 2017, h. 2, pada Tanggal 7 Juni 2017.

2Melina Marcori Indani, dkk, Akuntabilitas Dalam Pengelolaan Keuangan Daerah (Suatu Studi Pada Dinas Pendapatan Daerah Kabupaten Banggai Kepulauan), h. 1, pada Tanggal 8 Juni 2017. 
Dalam pasal 3 Undang-undang tersebut dinyatakan bahwa asas-asas kepastian hukum, asas tertib penyelenggaraan negara, asas kepentingan umum, asas keterbukaan asas proporsionalitas dan asas akuntabilitas dalam menyelenggarakan pasal tersebut dirumuskan bahwa, asas akuntabilitas adalah asas yang menentukan setiap kegiatan dan hasil akhir dari kegiatan penyelenggaraan negara harus dapat dipertanggungjawabkan kepada masyarakat dan rakyat sebagai pemegang kedaulatan tertinggi negara sesuai dengan ketentuan peraturan perundang-undangan yang berlaku. $^{3}$

Pemerintah telah menerbitkan Instruksi Presiden (Inpres) Nomor 7 Tahun 1999 tentang Akuntabilitas Kinerja Instansi Pemerintah. Hal tersebut diwajibkan bagi setiap instansi pemerintah sebagai unsur penyelenggaraan pemerintahan negara untuk mempertanggungjawabkan pelaksanaan tugas pokok dan fungsinya serta kewenangan pengelolaan sumber daya dengan didasarkan suatu perencanaan sinerjik yang ditetapkan oleh masing-masing instansi, pertanggungjawaban dimaksud berupa laporan yang disampaikan kepada atasan masing-masing. Laporan tersebut menggambarkan kinerja instansi pemerintah melalui sistem Akuntabilitas Kinerja Instansi Pemerintah. ${ }^{4}$

Terkhusus pada Instansi Badan Pengelolaan Keuangan dan Aset Daerah ini mempunyai tugas membantu Bupati dalam melaksanakan fungsi penunjang urusan pemerintahan daerah di bidang keuangan dan aset daerah yang menjadi kewenangan daerah. Dalam hal ini Badan Pengolaan Keuangan dan Aset Daerah Kabupaten Bone dibentuk berdasarkan Peraturan Bupati Bone Nomor 56 Tahun 2016 Tentang Pelaksanaan Peraturan Daerah Kabupaten Bone Nomor 8 Tahun 2016 Tentang

3Undang-Undang Republik Indonesia Nomor 28 Tahun 1995, Penyelenggaran Negara Yang Bersih Dan Bebas Dari Korupsi, Kolusi Dan Nepotisme, dalam http://www.unpad.ac.id/wpcontent/uploads/2016/03/UU-N0.-28-thn-1999.pdf, pada Tanggal 1 September 2017.

${ }^{4}$ Instruksi Presiden Republik Indonesia Nomor 7 Tahun 1999, Akuntabilitas Kinerja Instansi Pemerintah, dalam http://jatim.kemenag.go.id/file/file/peraturantentangPNS/jhom1413950080.pdf, pada Tanggal 1 September 2017. 
Pembentukan dan Susunan Perangkat Daerah. ${ }^{5}$ Sangatlah penting peranannya dalam rangka informasi dalam bidang pengelolaan keuangan dan aset daerah di Kabupaten Bone.

Kondisi inilah yang kemudian mendorong perlu dilakukannya reformasi anggaran agar pengalokasian anggaran lebih berorientasi pada kepentingan publik. Pentingnya efektivitas pengelolaan anggaran mulai dari penyusunan anggaran, pelaksanaan anggaran sampai dengan pelaporan/pertanggungjawaban anggaran karena dampaknya terhadap akuntabilitas pemerintah, sehubungan dengan fungsi pemerintah dalam memberikan pelayanan kepada masyarakat. Bentuk reformasi anggaran dalam upaya memperbaiki proses penganggaran adalah penerapan anggaran berbasis kinerja. ${ }^{6}$

Salah satu masalah penting yang menjadi penyenya adalah kurangnya akuntabilitas dan transparansi dalam pengelolaan keuangan pemerintah sebagai unsur dari suatu good govermance. Good govermance mengandung dua pengertian yaitu nilai-nilai yang menjunjung tinggi keinginan/kehendak rakyat dan nilai-nilai yang dapat meningkatkan kemampuan rakyat dalam pencapaian tujuan kemandirian, pembangunan berkelanjutan dan keadilan sosial. ${ }^{7}$

Masalah pengelolaaan keuangan daerah dan anggaran daerah merupakan aspek yang harus diatur secara hati-hati oleh pemerintah daerah. Pengelolaan keuangan daerah adalah keseluruhan kegiatan yang meliputi perencanaan, pelaksanaan, penatausahaan, pelaporan, pertanggungjawaban, dan pengawasan keuangan daerah dimana aspek yang sangat penting dalam pengelolaan keuangan daerah.

${ }^{5}$ Badan Pengelolaan Keuangan Dan Aset Daerah Kabupaten Bone, dalam http://bpkad.bone.go.id/sejarah-kantor/, pada Tanggal 19 Juli 2017.

${ }^{6}$ Adelstin Tamasoleng, "Analisis Efektivitas Pengelolaan Anggaran Di Kabupaten Kepulauan Siau Tagulandang Biaro", Jurnal Riset Bisnis dan Manajemen, Vol.3,No.1, 2015: 97-110, pada Tanggal 7 Juni 2017.

7Idhar Yahya, "Akuntabilitas Dan Transparansi Pengelolaan Keuangan Daerah", Jurnal Sistem Teknik Industri vol. 7, No. 4 Oktober 2006, h. 27, pada tanggal 9 Juli 2017. 
Pengelolaan keuangan daerah merupakan suatu kegiatan yang akan mempengaruhi peningkatan kesejahteraan dan kemakmuran rakyat, oleh karena itu pemerintah daerah menentukan target belanja daerah. Belanja daerah merupakansemua pengeluaran pemerintah pada satu periode anggaran. ${ }^{8}$ Setiap satuperiode (satu tahun) kepengurusan,pemerintah daerah menentukan target belanja pada setiap Satuan Kerja Pemerintah Daerah (SKPD). Target belanja daerah pada Badan Keuangan dan Aset Daerah di tentukan dalam tabel berikut ini :

Tabel : 1. Ringkasan Dokumen Pelaksanaan Perubahan Anggaran Satuan Kerja Perangkat Daerah Tahun 2014 - 2016.

Ringkasan Dokumen Pelaksanaan Perubahan Anggaran Satuan Kerja Perangkat Daerah Tahun 2014 - 2016

\begin{tabular}{|c|c|c|}
\hline \multirow{2}{*}{ Tahun } & \multicolumn{2}{|c|}{ Uraian Jumlah Belanja Daerah } \\
\cline { 2 - 3 } & $\begin{array}{c}\text { Belanja Langsung } \\
\text { (Rp) }\end{array}$ & Belanja Tidak Langsung (Rp) \\
\hline 2014 & 26.076 .056 .957 & 16.144 .101 .700 \\
\hline 2015 & 32.337 .572 .750 & 18.784 .013 .500 \\
\hline 2016 & 35.231 .133 .986 & 22.758 .192 .000 \\
\hline
\end{tabular}

Sumber: Badan Pengelolaan Keuangan Dan Aset Daerah Kab. Bone, Tahun 20142016.

${ }^{8}$ Abdul Halim, Akuntansi Sektor Publik-Akuntansi Keuangan Daerah (Jakarta: Salemba Empat; 2002), h. 68. ${ }^{8}$ Idhar Yahya, "Akuntabilitas Dan Transparansi Pengelolaan Keuangan Daerah", Jurnal Sistem Teknik Industri vol. 7, No. 4 Oktober 2006, h. 27, pada tanggal 9 Juli 2017.

${ }^{8}$ Abdul Halim, Akuntansi Sektor Publik-Akuntansi Keuangan Daerah (Jakarta: Salemba Empat; 2002), h. 68. 
Melihat dari target yang telah ditentukan oleh pemerintah daerah, maka Badan Pengelolaan Keuangan dan Aset Daerah hendaknya dapat mengelolah keuangan ini sebaik mungkin dan setiap belanja yang dikeluarkan hendaknya dapat dipertanggungjawabkan dalam laporan keuangan di setiap akhir periode. Salah satu prasyarat untuk mewujudkan hal tersebut adalah dengan melakukan reformasi dalam penyajian laporan keuangan, yakni pemerintah harus mampu menyediakan semua informasi keuangan relevan secara jujur dan terbuka kepada publik, karena kegiatan pemerintah adalah dalam rangka melaksanakan amanat rakyat. Penyajian laporan keuangan yang lengkap dan secara langsung tersedia dan aksebilitas bagi pengguna informasi menentukan sejauh mana akuntabilitas (pertanggungjawaban) pengelolaan keuangan daerah dan anggaran daerah tersebut.Kewajiban seluruh instansi baik di pemerintah pusat dan daerah untuk menyusun laporan keuangan sebagai wujud akuntabilitas pengelolaan keuangan daerah. ${ }^{9}$

Masalah yang sering terjadi dalam proses akuntabilitas yaitu pertanggungjawaban bagi aparat pemerintah masih belum sesuai yang diharapkan masyarakat pada umumnya karena instrumen yang digunakan tidak jelas lingkup dan penggunaannya, penyerapan anggaran di awal tahun masih rendah, situasi problematik telatnya SKPD dalam mengumumkan pengadaan Barang dan Jasa, perencanaan kegiatan/paket belanja SKPD kurang matang.

Dengan demikian, penelitian ini penting/perlu dilakukan untuk menilai lebih lanjut akuntabilitas pada suatu lembaga tertentu. Berdasarkan uraian latar belakang diatas, maka penulis dapat menarik rumusan masalah yang akan menjadi bahan penelitian antara lain sebagai berikut. Bagaimana implementasi akutanbilitas Pengelolaan Anggaran yang berbasis kinerja pada Badan Pengelolaan Keuangan Dan Aset Daerah Kab. Bone, Bagaimana kendala implementasi akuntabilitas Pengelolaan Anggaran yang berbasis kinerja pada Badan Pengelolaan Keuangan Dan Aset Daerah Kab. Bone dan

${ }^{9}$ Melina Marcori Indani, dkk. Akuntabilitas ..., h. 2. 
Bagaimana solusi terhadap kendala akuntabilitas Pengelolaan Anggaran yang berbasis kinerja pada Badan Pengelolaan Keuangan Dan Aset Daerah Kab. Bone.

\section{METODE}

1. Jenis dan Pendekatan Penelitian

a. Jenis Penelitian

Penelitian ini merupakan penelitian lapangan (Field Research) dengan menggunakan pendekatan kualitatif. Adapun yang dimaksud denganField Researchadalah penelitian yang dilakukan dengan terjun langsung ke lapangan untuk melakukan penelitian, dengan menggunakan beberapa teknik. ${ }^{10}$

b. Pendekatan Penelitian

Penelitian ini menggunakan pendekatan Kualitatif. Pendekatan Kualitatif merupakan metode penelitian lapangan. Pendekatan kualitatif berupaya memahami perilaku dan lembaga dengan memahami sebaik-baiknya orang-orang yang terlibat. Melalui perspektif ini, peneliti akan memahami berbagai masalah yang terdapat dalam kelompok tersebut. ${ }^{11}$

Pada pendekatan kualitatif, peneliti merupakan instrumen utama dalam pengumpulan data. Fokus penelitiannya pun ada pada persepsi dan pengalaman informan dan cara mereka memandang kehidupannya. Sehingga tujuannya bukan untuk memahami realita tunggal, tetapi realita majemuk. Penelitian kualitatif memusatkan perhatian pada proses yang berlangsung dan hasilnya. ${ }^{12}$

${ }^{10}$ Moh. Nazir, Metode Penelitian (Cet. III; Jakarta: Indonesia, 1988), h. 246.

${ }^{11}$ Baharuddin Ilyas dan Muhammad Arif Tiro, Metodologi Penelitian untuk IImu-IImu Sosial dan Ekonomi (Cet. 1; Makassar: Andira Publisher, 2002), h.241.

${ }^{12}$ Hamid Patilima, Metode Penelitian Kualitatif (Cet. 1; Bandung: Alfabeta, 2005), h. 65-66. 


\section{Lokasi Penelitian}

Lokasi penelitian pengelolaan anggaran belanja pada badan pengelolaan keuangan dan aset daerah adalah di Badan Pengelolaan Keuangan dan Aset Daerah yang terletak di Jl.H.A. Mappanyukki, Kec. Tanete Riattang Barat Kabupaten Bone Provinsi Sulawesi Selatan.

\section{Data dan Sumber Data}

Data adalah sumber informasi yang didapatkan oleh penulis, melalui penelitian yang dilakukan. Sumber data dalam penelitian adalah subjek darimana data dapat diperoleh. ${ }^{13}$ Maka untuk mendapatkan hasil penelitian yang valid dan akurat dalam penelitian ini, penulis menggunakan dua sumber data yaitu:

a. Data primer

Data Primer adalah data yang diperoleh langsung dari sumber data pertama dilokasi penelitian atau objek penelitian (sumber asli). ${ }^{14}$

b. Data sekunder

Data sekunder adalah data yang diperoleh dari sumber kedua atau sumber sekunder dari salah satu yang peneliti butuhkan. Data sekunder yang digunakan dalam penelitian ini seperti dokumentasi, artikel jurnal, buku-buku yang terkait dengan penelitian, surat kabar, majalah, artikel, internet dan sumber lain yang membahas tentang penelitian ini. ${ }^{15}$

\section{Teknik Pengumpulan Data}

${ }^{13}$ Suharamis Arikonto, Penelitian Suatu Pendekatan Praktek (Cet. XII; Jakarta: Rineka Cipta, 2002), h. 107.

${ }^{14}$ Burhan Bungin, Metodologi Penelitian Kuantitatif (Jakarta: Kencana Prenada Media Group. 2009), h. 122.

15Burhan Bungin, Metodologi Penelitian Kuantitatif..., h. 123. 
Teknik pengumpulan data yang digunakan peneliti yaitu Field Research. Field Research (Riset Lapangan) yaitu pengumpulan data-data lewat penelitian lapangan, melalui observasi, wawancara dan dokumentasi

\section{HASIL DAN PEMBAHASAN}

\section{Implmentasi Akuntabilitas Pengelolaan Anggaran Pada Badan Pengelolaan Keuangan dan Aset daerah (BPKAD) Kab. Bone}

Dalam kegiatan pengelolaan anggaran pada Badan Pengelolaan Keuangan dan Aset Daerah (BPKAD) Kab. Bone dilakukan dengan memperhatikan 4 (empat) prinsip akuntabilitas yang dilaksanakan. Adapun keempat prinsip yang dimaksud yaitu perencanaan, penganggaran, pelaksanaan, dan pertanggungjawaban.

a. Perencanaan Anggaran

Peraturan Menteri dalam Negeri Republik Indonesia Nomor. 52 Tahun 2015 tentang Pedoman Penyusunan Anggaran Pendapatan Belanja Daerah mengenai kebijakan penyusunan APBD yang di atur berdasarkan UU Nomor 23 Tahun 2014 belanja daerah yang terbagi menjadi belanja langsung dan tidak langsung. Pada tahap perencanaan yaitu menginvestasi, identifikasi dan memetakan permasalahan kemudian pada tahap penyampaian adalah melihat proposal dan kegiatan, kebijakan kewajaran alokasi anggaran dan pertanggungjawaban yaitu mengecek laporan keuangan sudah sesuai dengan perencanaan

Adapun perencanaan anggaran yang dimaksud sebagai berikut:

Tabel :2 Pedoman Perencanaan Penyusunan Anggaran Pendapatan dan Belanja

\section{Daerah}

Pedoman Perencanaan Penyusunan Anggaran Pendapatan dan Belanja Daerah Belanja Tidak Langsung Belanja Langsung 


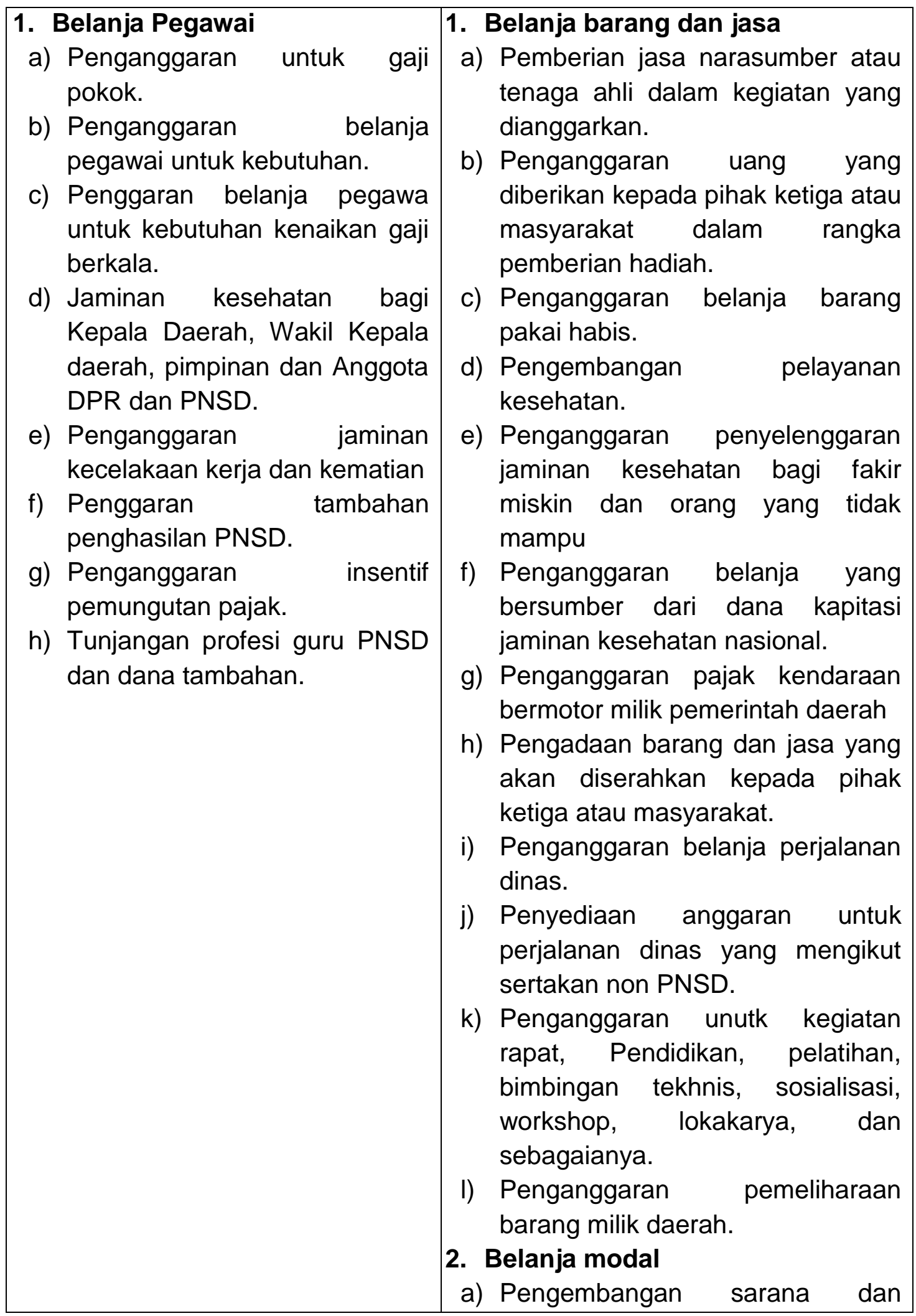

Jurnal Ilmiah Al Tsarwah

Program Magister Program Studi Ekonomi Syariah

Institut Agama Islam Negeri (IAIN) Bone 


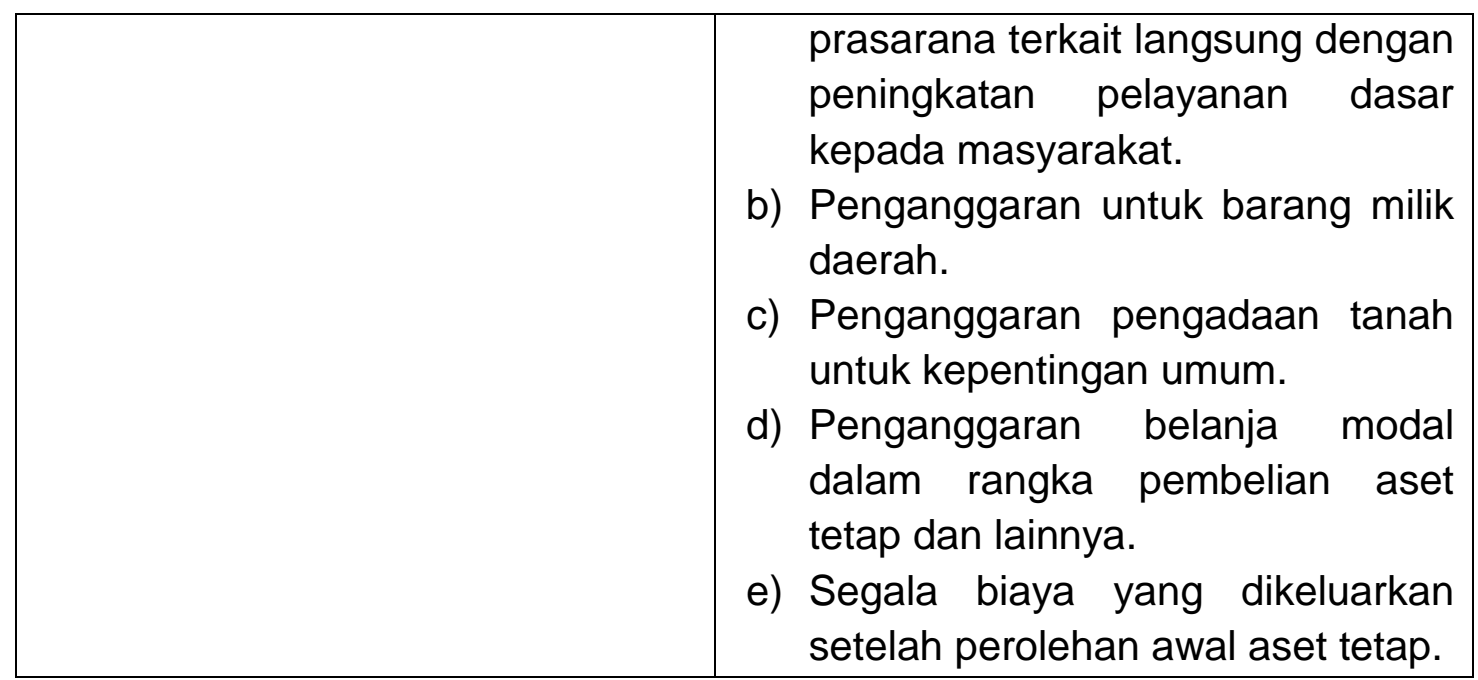

Sumber: Pedoman Penyusunan Anggaran Pendapatan dan Belanja Daerah Tahun Anggaran 2016.

Dari ketentuan tersebut kepala Sub. Bidang Perencanaan Anggaran, mengemukakan bahwa:

"Bentuk perencanaan pengelolaan anggaran yang dilakukan oleh BPKAD Kab. Bone berdasarkan Renstra, RPJMD, Renja, RKPD, RKA-RDPPA sedangkan prosesnya yaitu penyusunan proposal dan kegiatan, penyusunan RKA-RDPPA dan penyusunan DPA-DPPA". ${ }^{16}$

Penjabaran tersebut bagian dari tahapan-tahapan bentuk perencanaan dalam mengelola anggaran telah mengacu pada pola dasar sesuai dengan visi dan misi dan utama menjadi perhatian kelembagaan Badan Pengelolaan Keuangan dan Aset daerah Kabupaten Bone. Sehubungan dengan hal yang dimaksud perencanaan anggaran dapat terealisasi sesuai dengan potensi dan kemampuan seluruh pemangku kepentingan di Kabupaten Bone serta diarahkan masyarakat yang cerdas, sehat dan sejahtera, merupakan upaya konkrit mewujudkan transparansi dan akuntabilitas pengelolaan keuangan daerah telah sesuai dengan aturan yang berlaku.

Berdasarkan aturan yang berlaku pada BPKAD Kab. Bone dalam menetapkan capaian kinerja setiap belanja telah berbasis kinerja karena proses perencanaan

\footnotetext{
${ }^{16}$ Bustan, "Wawancara” (Kepala Sub Bidang Perencanaan Anggaran) pada hari Jumat Tanggal 21 Oktober 2017, Pukul 09.00-09.30, di Badan Pengelolaan Keuangan dan Aset Daerah (BPKAD) Kabupaten Bone.
} 
anggaran yang dilakukan oleh BPKAD Kab. Bone telah sesuai peraturan dalam negeri Nomor. 13 Tahun 2016 sesuai yang dikemukakan oleh kepala Bidang Anggaran bahwa:

"Bahwa semua kegiatan yang ada di BPKAD Kab. Bone dapat diukur kinerjanya baik output maupun outcame sehingga kinerja suatu kegiatan dapat tercapai". ${ }^{17}$

Pendapat informan tersebut memperjelas efektifitas dan efisiensi penyusunan anggaran serta meningkatkan akuntabilitas perencanaan anggaran yang baik dalam konteks daerah, satuan kerja perangkat daerah maupun program dan kegiatan sehingga dapat dirasakan langsung oleh masyarakat dalam rangka peningkatan kualitas pelayanan publik yang telah sesuai dengan ketentuan perundang-undangan.

\section{Penganggaran}

Pengelolaan keuangan daerah merupakan kegiatan yang akan mempengaruhi peningkatan kesejahteraan dan kemakmuran rakyat, oleh karena itu pemerintah daerah menentukan target belanja daerah. Setiap periode (satu tahun) kepengurusan, pemerintah daerah dalam menentukan target belanja setiap Satuan pemerintah Daerah (SKPD). Target belanja daerah pada BPKAD di tentukan dalam tabel sebagai berikut ini

Perumusan penganggaran yang telah dikemukakan tersebut telah melalui mekanisme yang ada setiap kegiatan dilaksanakan sesuai dengan dokumen pelaksanaan anggaran pada BPKAD dan tidak boleh melebihi dari apa yang direncanakan dalam dokumentasi pelaksanaan anggaran serta menerima usulan rencana anggaran masing-masing bidang untuk dijadikan acuan dalam menetapkan sebuah anggaran sehingga pelaksanaan pengaggaran daerah sesuai tugas dan tanggungjawabnya.

Penyusunan anggaran belanja pada setiap program dan kegiatan untuk urusan pemerintah wajib yang tidak terkait dengan pelayanan dasar dan urusan pemerintah

\footnotetext{
${ }^{17}$ Andi Hasanuddin, "Wawancara" (Kepala Bidang Anggaran) pada hari Jumat Tanggal 21 Oktober 2017, Pukul 09.40-10.20, di Badan Pengelolaan Keuangan dan Aset Daerah (BPKAD) Kabupaten Bone.
}

Jurnal Ilmiah Al Tsarwah

Program Magister Program Studi Ekonomi Syariah

Institut Agama Islam Negeri (IAIN) Bone 
pilihan berpedoman pada standar belanja dan standar harga satuan regional. Alokasi belanja untuk program dan kegiatan masing-masing urusan pemerintah tersebut di atas digunakan sebagai dasar penyusunan RKA-SKPD. Sesuai yang dikemukakan oleh kepala Sub. Bidang Perbendaharaan bahwa:

"kegiatan pelaksanaan penganggaran yang dilakukan BPKAD Kab. Bone yaitu dengan menyesuaikan dengan kebutuhan, kemudian menyusun dalam rencana kerja anggaran (RKA) berdasarkan KUA PPAS". ${ }^{18}$

Berdasarkan KUA dan PPAS yang telah disepakati Bersama antara kepala daerah dan DPRD, kepala daerah mengeluarkan pedoman penyusunan RKA-SKPD yang mencakup prioritas pembangunan daerah, program dan kegiatan sesuai indikator, tolak ukur dan target kinerja dan masing-masing program kegiatan serta sesuai dengan peraturan perundang-undangan.

\section{Pelaksanaan Anggaran}

Beberapa aspek dalam pelaksanaan anggaran memberikan peran dan tanggung jawab yang lebih besar kepada pejabat pelaksana anggaran, sistem pengawasan pengeluaran, serta pelaporan akuntansi, hal tersebut di pertegas oleh Sub. Bidang Perencanaan Anggaran Belanja Langsung BPKAD Kab. Bone, beliau menyatakan bahwa:

Berdasarkan Undang-Undang Nomor 1 tahun 2004 tentang Perbendaharaan Negara pasal 51 ayat (2), Kepala Satuan Kerja Perangkat Daerah (SKPD) selaku Pengguna Anggaran harus menyelenggarakan akuntansi atas transaksi keuangan,

\footnotetext{
${ }^{18}$ Andi Yulianto, "Wawancara" (Sub Bidang Perbendaharaan) pada hari Jumat Tanggal 21 Oktober 2017, Pukul 11.10-11.30, di Badan Pengelolaan Keuangan dan Aset Daerah (BPKAD) Kabupaten Bone.
} 
aset, utang, dan ekuitas dana, termasuk transaksi pendapatan dan belanja, yang berada dalam tanggung jawabnya. Hal ini berarti bahwa setiap SKPD harus membuat laporan keuangan unit kerja. Pasal 56 UU ini menyebutkan bahwa laporan keuangan yang harus dibuat setiap unit kerja adalah Laporan Realisasi Anggaran, Neraca, dan Catatan atas Laporan Keuangan, sedangkan yang menyusun laporan arus Kas adalah Kepala Satuan Kerja Pengelola Keuangan Daerah selaku Bendahara Umum daerah.

Berdasarkan Peraturan Pemerintah Republik Indonesia Nomor 58 Tahun 2005 tentang Pengelolaan Keuangan Daerah pasal 1 ayat (48), Dokumen Pelaksanaan Anggaran SKPD yang selanjutnya disingkat DPA-SKPD merupakan dokumen yang memuat pendapatan dan belanja setiap SKPD yang digunakan sebagai dasar pelaksanaan oleh pengguna anggaran.

Berdasarkan Peraturan Menteri Dalam Negeri Nomor 13 Tahun 2006 tentang Pedoman Pengelolaan Keuangan Daerah pasal 1 ayat (61), Dokumen Pelaksanaan Anggaran SKPD yang selanjutnya disingkat DPA-SKPD adalah dokumen yang memuat pendapatan, belanja dan pembiayaan yang digunakan sebagai dasar pelaksanaan anggaran oleh pengguna anggaran.

4. Pertanggungjawaban Anggaran

Badan Pengelolaan Keuangan dan Aset Daerah terbuka, optimal dan prima dalam mewujudkan visi Kabupaten Bone melalui pengelolaan keuangan yang akuntabel. Pelayanan terbuka dijabarkan bahwa Badan Pengelolaan Keuangan dan Aset Daerah senantiasa terbuka, dalam pengelolaan keuangan daerah diwujudkan dalam bentuk penyusunan APBD dan pertanggungjawabannya menjadi dokumen publik.Sesuai yang dikemukakan oleh Kepala Sekretariat menyatakan bahwa:

Jurnal Ilmiah Al Tsarwah

Program Magister Program Studi Ekonomi Syariah

Institut Agama Islam Negeri (IAIN) Bone 
"Dalam penerapan prinsip prtanggungjawaban pengelolaan anggaran BPKAD Kab. Bone yaitu Bersih, Transparan dan Akuntabel". ${ }^{19}$

Bentuk transparansi tersebut yaitu dengan memuat pada beberapa media lokal maupun nasional serta memuat pada beberapa media online dan juga melalui website BPKAD terbukti hal ini sebagai upaya konkrit untuk mewujudkan transparasi dan akuntabilitas pengelolaan keuangan daerah adalah penyampaianlaporan pertanggungjawaban keuangan pemerintah daerah memenuhi prinsip-prinsip tepat waktu dan disusun sesuai standar akuntasi pemerintah yang telah diterima secara umum. Dalam ketentuan pengelolaan keuangan daerah ditetapkan bahwa laporan pertanggungjawaban pelaksanaan APBD disampaikan berupa laporan keuangan sesuai standar akuntansi pemerintah.

Sehingga dalam pengelolaan keuangan dan aset daerah, diperlukan tahapantahapan perencanaan, pelaksanaan, dan pengawasan, secara sistematis, sinergis dan konprehensif yang mengarah pada pencapaian visi, dan misi Kabupaten Bone sebagaimana tertuang dalamRPJMD 2013-2018.

Sehubungan dengan hal dimaksud, Badan Pengelolaan Keuangan dan Aset Daerah berkewajiban menyusun Rencana Strategis (Restra) berdasarkan skala prioritas kegiatan pembangunan yang dapat direalisasikan sesuai dengan potensi dan kemampuan seluruh pemangku kepentingan di Kabupaten Bone. Serta tetap memperhatikan kebijakan dari Bupati yang disertai kekuasaan atas pengelolaan keuangan negara dari presiden dengan mempertimbangkan Pembangunan Kabupaten Bone tahun 3013-2018, sesuai Rencana Pembangunan Jangka Menengah Daerah (RPJMD) diarahkan masyarakat yang cerdas, sehat dan sejahtera. Hal tersebut telah menjadi kesepakatan antara seluruh stakeholder yaitu Pemerintah daerah, DPRD, kelompok-kelompok masyarakat baik yang bergerak di bidang sosial dan budaya, ekonomi maupun politik dan keamanan.

${ }^{19} \mathrm{H}$. Najamuddin, "Wawancara” (Kepala Sekretariat) pada hari Jumat Tanggal 21 Oktober 2017, Pukul 11.40-12.10, di Badan Pengelolaan Keuangan dan Aset Daerah (BPKAD) Kabupaten Bone. 
Kendala Implementasi Akuntabilitas Pengelolaan Anggaran yang Berbasis Kinerja pada Badan Pengelolaan Keuangan Dan Aset Daerah Kab. Bone

Badan Pengelolaan Keuangan dan Aset Daerah (BPKAD) Bone menyebutkan sedikitnya ada 3 kelemahan yang menjadi kendala utamadalam proses pembenahan aset daerah yang selama ini menjadi bumerang sehingga Kabupaten Bone tidak bisa mendapati predikat Wajar Tanpa Pengecualian (WTP) dari Badan Pemeriksaan Keuangan (BPK). Ke tiga kendala tersebut yakni:

Pertama lemahnya Satuan Kerja Perangkat Daerah (SKPD) dalam menjaga komitmen untuk melakukan pembenahan aset dilingkup masing-masing. Para Kepala SKPD cenderung mengabaikan persoalan aset dari pejabat sebelumnya, kendati sudah ada teguran bahkan rekomendasi dari BPK setelah melakukan pemeriksaan.

Kedua, Kelemahan pada Sumber Daya Manusia (SDM) dari perangkat SKPD yang bertanggung jawab dalam pengelolaan aset mulai dari pengurus Barang, Bendahara Barang sampai pada Pejabat Pelaksanaan Teknis Kegiatan (PPTK), mereka tidak paham mekanisme pengelolaan aset. Sesuai yang dikemukakan oleh Kepala Sub. Bidang Perencanaan Anggaran menyatakan bahwa:

"Ada beberapa kendala yang terjadi dalam pelaksanaan pengelolaan anggaran yaitu Sumber Daya Manusia dan Koordinasi dalam penyusunan anggaran”. ${ }^{20}$

Sementara kendala yang ketiga, terkait persoalan finansial dari para perangkat SKPD dalam mendata bengkalai asset yang berada baik diunit kerjanya masingmasing, maupun di SKPD. Hal tersebut di sekan oleh beberapa faktor, termasuk persoalan komitmen dari para perangkat penanggung jawab, maupun keterbatasan SDM.

\section{Solusi Terhadap Kendala Akuntabilitas Pengelolaan Anggaran Yang Berbasis Kinerja Pada Badan Pengelolaan Keuangan Dan Aset Daerah Kab. Bone}

\footnotetext{
${ }^{20}$ Bustan, "Wawancara" (Kepala Sub Bidang Perencanaan Anggaran) pada hari Jumat Tanggal 21 Oktober 2017, Pukul 09.00-09.30, di Badan Pengelolaan Keuangan dan Aset Daerah (BPKAD) Kabupaten Bone.
} 
Badan Pengelolaan Keuangan Dan Aset Daerah (BPKAD) Kabupaten Bone dalam melaksanakan tugas dan fungsi sebagai perangkat Daerah Kabupaten Bone, sangat ditentukan kinerja staf namun juga dipengaruhi oleh peran SKPD terkait dalam menyampaikan informasi, laporan dan data secara akurat dan tepat waktu. Sesuai yang dikemukakan Kepala Sekretariat bahwa:

"Dalam pelaksanaan pengelolaan anggaran oleh BPKAD tidak terdapat kendala sepanjang disesuaikan dengan kegiatan yang ada, karena telah mengikuti scedul". ${ }^{21}$

Ungkapan tersebut bagian dari solusi yang dapat menciptakan pelayanan kantor yang baik dan menciptakan aparat BPKAD yang berkualitas yang mampu menjalankan tugas dan fungsinya dengan efektif, efisien, transparan dan akuntabel, dan meningkatkan pendapatan dari hasil pengelolaan aset daerah yang di pertanggungjawabkan, serta meningkatnya kualitas pengelolaan aset daerah.

Sebelum laporan pertanggungjawaban setiap karyawan diterima terlebih dahulu dilakukan evaluasi secara administratif atas laporan keuangan yang dibuat demi menghindari kesalahan dalam penulisan laporan keuangan. Hal tersebut di benarkan oleh Sub. Bidang perencanaan anggaran belanja langsung Badan Pengelolaan Keuangan dan Aset Daerah Kab. Bone bahwa:

"Membenahi secara administratif melalui analisis dan evaluasi kinerja setiap pelaksanaan program dan kegiatan".22

Sehingga proses pengelolaan anggaran yang berbasis kinerja yaitu pemahaman terhadap petunjuk teknis ditingkatkan pemantapan dalam perencanaan dan koordinasi mengoptimalkan penyelenggaraan tugas pokok dan fungsi, hingga dianggap penyelenggaran urusan perkantoran dan pelayanan masyarakat menjadi tepat sasaran.

${ }^{21} \mathrm{H}$. Najamuddin, "Wawancara” (Kepala Sekretariat) pada hari Jumat Tanggal 21 Oktober 2017, Pukul 11.40-12.10, di Badan Pengelolaan Keuangan dan Aset Daerah (BPKAD) Kabupaten Bone.

${ }^{22}$ Awaluddin, "Wawancara" (Sub. Bidang Perencanaan Anggaran Belanja Langsung) pada hari Jumat Tanggal 21 Oktober 2017, Pukul 11.40-12.10, di Badan Pengelolaan Keuangan dan Aset Daerah (BPKAD) Kabupaten Bone. 


\section{KESIMPULAN DAN SARAN}

\section{Kesimpulan}

Berdasarkan hasil analisis dan pembahasan di atas, maka dapat ditarik kesimpulan sebagai berikut:

a. Dalam kegiatan pengelolaan anggaran pada Badan Pengelolaan Keuangan dan Aset Daerah (BPKAD) Kabupaten Bone dilakukan dengan memperhatikan 4 (empat) prinsip akuntabilitas yang dilaksanakan yaitu perencanaan anggaran, penganggaran, pelaksanaan anggaran, dan pertanggungjawaban anggaran. Bentuk perencanaan pengelolaan anggaran yang dilakukan oleh BPKAD Kab. Bone berdasarkan Renstra, RPJMD, Renja, RKPD, RKA-RDPPA sedangkan prosesnya yaitu penyusunan proposal dan kegiatan, penyusunan RKA-RDPPA dan penyusunan DPA-DPPA. Kegiatan pelaksanaan penganggaran yang dilakukan BPKAD Kabupaten Bone yaitu dengan menyesuaikan dengan kebutuhan, kemudian menyusun dalam rencana kerja anggaran (RKA) berdasarkan KUA PPAS. Pertimbangan pelaksanaan penganggaran yang dilakukan BPKAD Kabupaten Bone yaitu berdasarkan pada dasar hukum UU Nomor 1 Tahun 2004 tentang Perbendaharaan Negara, PP Nomor 58 Tahun 2005 tentang Pengelolaan Keuangan Daerah, dan Permendagri Nomor 13 Tahun 2016 tentang Pedoman Pengelolaan Keuangan Daerah. Dalam ketentuan pengelolaan keuangan daerah ditetapkan bahwa laporan pertanggungjawaban pelaksanaan APBD disampaikan berupa laporan keuangan sesuai standar akuntansi pemerintah.

b. Dalam pengelolaan anggaran ada beberapa kendala yang terjadi dalam pelaksanaan pengelolaan anggaran yaitu Sumber Daya Manusia dan Koordinasi dalam penyusunan anggaran. Kelemahan pada Sumber Daya Manusia (SDM) dari perangkat SKPD yang bertanggung jawab dalam pengelolaan aset mulai dari pengurus Barang, Bendahara Rorıng sampai pada Pejabat Pelaksanaan Teknis Kegiatan (PPTK), mereka tidal , ${ }^{53}$ mekanisme pengelolaan aset. 
c. Solusi terhadap pelaksanaan pengelolaan anggaran oleh BPKAD dapat terselesaikan, sepanjang disesuaikan dengan kegiatan yang ada dan mengikuti scedul. Sehingga proses pengelolaan anggaran yang berbasis kinerja yaitu pemahaman terhadap petunjuk teknis ditingkatkan pemantapan dalam perencanaan dan koordinasi mengoptimalkan penyelenggaraan tugas pokok dan fungsi, hingga dianggap penyelenggaraan urusan perkantoran dan pelayanan masyarakat menjadi tepat sasaran.

\section{Saran}

Berdasarkan kesimpulan di atas maka dapat disarankan sebagai berikut:

Kegiatan pengelolaan anggaran perlu adanya sosialisasi yang lebih maksimal kepada pihak-pihak yang bertanggungjawab dengan cara musyawara mufakat Tim Anggaran Pemerintah Daerah atas kendala-kendala dalam mengelola anggaran pada Badan Pengelolaan Keuangan dan Aset Daerah Kabupaten Bone.

\section{DAFTAR PUSTAKA}

Akdon, Strategic Management For Educational Mnagement, Bandung: Alfabeta, 2006.

Anugriani, Rezky Mulya, "PengaruhAkuntabilitas, Transparansi, Dan PengawasanTerhadapKinerjaAnggaranBerkonsep Value For Money PadalnstansiPemerintah Di Kabupaten Bone”, Skripsi,jurusanakuntansi, fakultasekonomidanbisnis, universitashasanuddinmakassar.

Arikonto, Suharamis,PenelitianSuatuPendekatanPraktek, Cet. XII; Jakarta: RinekaCipta, 2002.

Awaluddin, "Wawancara" (Sub BidangPerencanaanAnggaranBelanjaLangsung) padahariJumatTanggal 21 Oktober 2017, Pukul 11.45 - 12.35, di BadanPengelolaanKeuangandanAset Daerah (BPKAD) Kab. Bone.

BadanPengelolaanKeuangan Dan Aset Daerah Kabupaten Bone, dalamhttp://bpkad.bone.go.id/sejarah-kantor/, padaTanggal 19 Juli 2017.

BadanPengelolaanKeuangandanAset Daerah Kabupaten Bone, RENSTRA, (BPKAD 2013-2018), h. 8.

Bungin, Burhan, MetodologiPenelitianKuantitatif, Jakarta: KencanaPrenada Media Group. 2009.

Bustan, "Wawancara" (Kepala Sub BidangPerencanaanAnggaran) padahariJumatTanggal 21 Oktober 2017, Pukul 09.00-09.30, di BadanPengelolaanKeuangandanAset Daerah (BPKAD) Kabupaten Bone. 
Departemen Pendidikan Nasional, kamusbesarbahasa Indonesia, Jakarta: Pusat Bahasa, 2008.

H. Najamuddin, "Wawancara" (KepalaSekretariat) padahariJumatTanggal 21 Oktober 2017, Pukul 11.40-12.10, di BadanPengelolaanKeuangandanAset Daerah (BPKAD) Kabupaten Bone.

Halim, Abdul, AkuntansiSektorPublik-AkuntansiKeuangan Daerah, Jakarta: SalembaEmpat; 2002.

Hasanuddin, Andi, "Wawancara" (KepalaBidangAnggaran) padahariJumatTanggal 21 Oktober 2017, Pukul 09.40-10.20, di BadanPengelolaanKeuangandanAset Daerah (BPKAD) Kabupaten Bone.

llyas, Baharuddindan Muhammad ArifTiro, MetodologiPenelitianuntukllmuIImuSosialdanEkonomi, Cet. 1; Makassar: Andira Publisher, 2002. 